Nevada

Environmental

Restoration

Project

Addendum to the Corrective Action

Decision Document/Closure Report for

Corrective Action Unit 406: Area 3

Building 03-74 \& Building 03-58

Underground Discharge Points and

Corrective Action Unit 429: Area 3

Building 03-55 \& Area 9 Building 09-52

Underground Discharge Points,

Tonopah Test Range, Nevada

Controlled Copy No.:

Revision No.: 0

October 2008

Approved for public release; further dissemination unlimited.

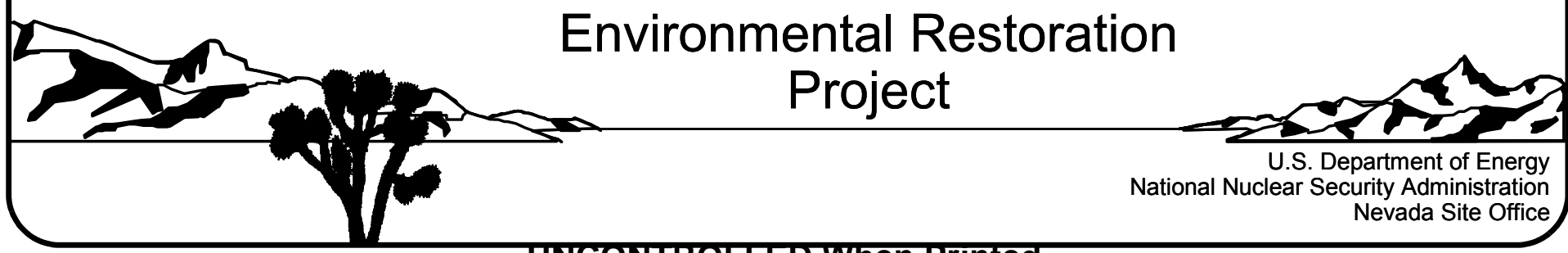


Available for public sale, in paper, from:

U.S. Department of Commerce

National Technical Information Service

5285 Port Royal Road

Springfield, VA 22161

Phone: 800.553 .6847

Fax: 703.605.6900

Email: orders@ntis.gov

Online ordering: http://www.ntis.gov/ordering.htm

Available electronically at $\underline{h t p: / / w w w . o s t i . g o v / b r i d g e ~}$

Available for a processing fee to U.S. Department of Energy and its contractors, in paper, from:

U.S. Department of Energy

Office of Scientific and Technical Information

P.O. Box 62

Oak Ridge, TN 37831-0062

Phone: 865.576 .8401

Fax: 865.576.5728

Email: reports@adonis.osti.gov

Reference herein to any specific commercial product, process, or service by trade name, trademark, manufacturer, or otherwise, does not necessarily constitute or imply its endorsement, recommendation, or favoring by the United States Government or any agency thereof or its contractors or subcontractors. 


\title{
ADDENDUM TO THE CORRECTIVE ACTION DECISION DOCUMENT/CLOSURE REPORT FOR CORRECTIVE ACTION UNIT 406: AREA 3 BUILDING 03-74 \& BUILDING 03-58 UNDERGROUND DISCHARGE POINTS AND CORRECTIVE ACTION UNIT 429: AREA 3 BUILDING 03-55 \& AREA 9 BUILDING 09-52 UNDERGROUND DISCHARGE POINTS, TONOPAH TEST RANGE, NEVADAA
}

\author{
U.S. Department of Energy \\ National Nuclear Security Administration \\ Nevada Site Office \\ Las Vegas, Nevada
}

Controlled Copy No.:

Revision No.: 0

October 2008

Approved for public release; further dissemination unlimited. 


\section{Addendum to the Corrective Action Decision Document / Closure Report for Removal of the Use Restriction}

This document constitutes an addendum to the March 2000, Corrective Action Decision Document / Closure Report for Corrective Action Unit 406: Area 3 Building 03-74 \& 03-58 Underground Discharge Points and Corrective Action Unit 429: Area 3 Building 03-55 \& Area 9 Building 09-52 Underground Discharge Points (TTR) as described in the document Recommendations and Justifications for Modifications for Use Restrictions Established under the U.S. Department of Energy, National Nuclear Security Administration Nevada Site Office Federal Facility Agreement and Consent Order (UR Modification document) dated February 2008. The UR Modification document was approved by NDEP on February 26, 2008. The approval of the UR Modification document constituted approval of each of the recommended UR modifications. In conformance with the UR Modification document, this addendum consists of:

- This cover page that refers the reader to the UR Modification document for additional information

- The cover and signature pages of the UR Modification document

- The NDEP approval letter

- The corresponding section of the UR Modification document

This addendum provides the documentation justifying the cancellation of the UR for CAS 03-51-001-0355 - Photo Shop UDP, Drains in CAU 429. It should be noted that there are no changes to CAU 406. This UR was established as part of a Federal Facility Agreement and Consent Order (FFACO) corrective action and is based on the presence of contaminants at concentrations greater than the action levels established at the time of the initial investigation (FFACO, 1996; as amended August 2006).

Since this UR was established, practices and procedures relating to the implementation of risk-based corrective actions (RBCA) have changed. Therefore, this UR was re-evaluated against the current RBCA criteria as defined in the Industrial Sites Project Establishment of Final Action Levels (NNSA/NSO, 2006c). This re-evaluation consisted of comparing the original data (used to define the need for the UR) to risk-based final action levels (FALs) developed using the current Industrial Sites RBCA process.

The re-evaluation resulted in a recommendation to remove the UR because contamination is not present at the site above the risk-based FALs. Requirements for inspecting and maintaining this UR will be canceled, and the postings and signage at this site will be removed. Fencing and posting may be present at this site that are unrelated to the FFACO UR such as for radiological control purposes as required by the $N V / Y M P$ Radiological Control Manual (NNSA/NSO, 2004f). This modification will not affect or modify any non-FFACO requirements for fencing, posting, or monitoring at this site. 
Nevada

Environmental

Restoration

Project

Recommendations and Justifications for Modifications for Use Restrictions Established under the U.S. Department of Energy, National Nuclear Security Administration Nevada Site Office

Federal Facility Agreement and Consent Order

Controlled Copy No.:

Revision No.: 0

February 2008

Approved for public release; further dissemination unlimited.

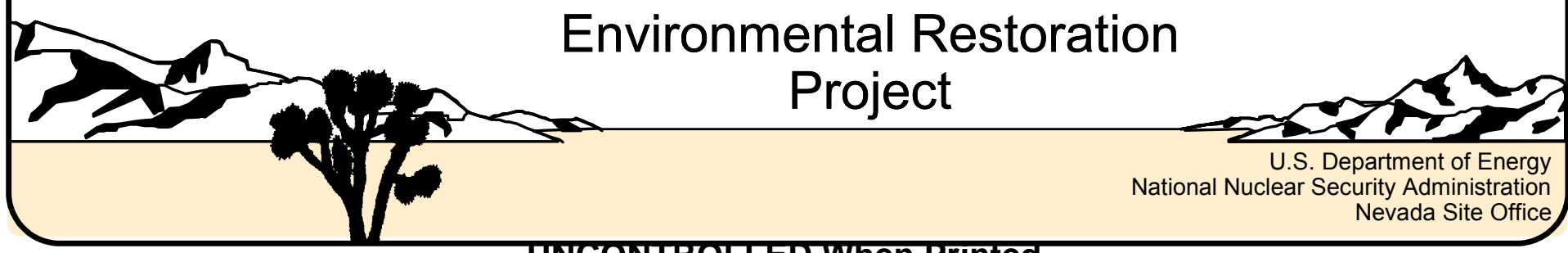


Recommendations and Justifications for Modifications for Use Restrictions Established under the U.S. Department of Energy, National Nuclear Security Administration Nevada Site Office Federal Facility Agreement and Consent Order

Approved by: /s/ Kevin J. Cabble

Date: $02 / 05 / 2008$

Kevin J. Cabble

Federal Sub-Project Director

Industrial Sites Sub-Project

Approved by:

/s/ John B. Jones

Date: $02 / 04 / 2008$

John B. Jones

Acting Federal Project Director

Environmental Restoration Project 
February 26, 2008

John B. Jones

Acting Federal Project Director

Environmental Restoration Project

National Nuclear Security Administration

Nevada Site Office

P. O. Box 98518

Las Vegas, NV 89193-8518

RE: Approval of Recommendations and Justifications for Modifications for Use Restrictions

Established under the U.S. Department of Energy, National Nuclear Security Administration, Nevada Site Office Federal Facility Agreement and Consent Order

Dear Mr. Jones:

The Nevada Division of Environmental Protection, Bureau of Federal Facilities (NDEP) staff has received and reviewed the February 2008 final report for Recommendations and Justifications for Modifications for Use Restrictions Established under the U.S. Department of Energy, National Nuclear Security Administration, Nevada Site Office. The NDEP approves the requested changes to the previously agreed upon use restrictions for those Corrective Action Sites (CASs) as described in the report.

Address any questions regarding this matter to either Ted Zaferatos at (702) 486-2850, ext. 234 , or me at (702) 486-2850, ext. 231.

Sincerely

\section{/s/ Tim Murphy}

\section{T.H. Murphy}

Chief

Bureau of Federal Facilities

$\mathrm{TZ}$

cc: $\quad$ E.F. DiSanza, WMP, NNSA/NSO

FFACO Group, PSG, NNSAINSO, Las Vegas, NV

David C. Loewer, DTRAVCXT1, M/S 645, Mercury, NV

W.R. Griffin, SNJV/DTRA, M/S 645, Mercury, NV

T.A. Thiele, NSTec, Las Vegas, NV

R.F. Boehlecke, SNJV, Las Vegas, NV

K. J. Cabble, ERP, NNSANSO, Las Vegas, NV

John Wong. Jeff MacDougall, Dennis Nicodemus, NDEP Las Vegas, NV 


\subsection{CAU 429, CAS 03-51-001-0355 - Photo Shop UDP, Drains}

\subsection{CAS Description}

Process knowledge indicates that potentially contaminated effluent was discharged to UDPs at CAU 429 from various operations at the TTR. The UDPs are subgrade shallow dry wells or excavations filled with gravel. Effluent was discharged to the UDPs through drainage pipes and allowed to percolate into the surrounding soil. Soils surrounding UDPs have likely been impacted by wastewater containing chemicals associated with maintenance (e.g., hydrocarbons or solvents) and/or photo-processing operations (e.g., silver) (DOE/NV, 2000b).

The Area 3 Photoshop (Building 03-55) UDPs were located in the southeast corner of the Area 3 compound. The configuration of each UDP varied. The primary UDP (B1-0355) consisted of a 3-ft-diameter, corrugated steel lining with an overflow pipe located approximately $1.5 \mathrm{ft}$ bgs. The secondary UDP (B2-0355) had a void space to $8 \mathrm{ft}$ bgs, which was backfilled before drilling. The actual depth of the steel lining for both UDPs was not confirmed. The original discharge pipe from Building 03-55 to the primary UDP was rerouted $15 \mathrm{ft}$ south of Building 03-55. The remaining length of pipe appears to be intact and was identified as 4-in. diameter transite pipe located approximately $3 \mathrm{ft}$ bgs (DOE/NV, 2000b).

\subsection{Current Use Restriction Description}

The future use of any land affected by this UR is restricted from any DOE or Air Force activity that may alter or modify the containment control, as approved by the state and identified in the CAU CR or other CAU documentation, unless appropriate concurrence is obtained in advance. There are no site monitoring requirements. The CAS 03-51-001-0355 UR is for future utilization for residential purposes. There are no restrictions for future industrial activities (e.g., excavation for utility installation or maintenance) at the site (DOE/NV, 2000b).

\subsection{Basis for Current Use Restriction}

Samples were analyzed for total VOCs, total SVOCs, and total RCRA metals. In addition, select samples were analyzed for TCLP-silver and isotopic U. All concentrations of VOCs and SVOCs in soil samples were below the PALs at both CASs. All concentrations of total RCRA metals in soil samples were below PALs established in the CAIP (DOE/NV, 1999d) except for arsenic. Although the concentrations of arsenic exceeded the PAL of $3.0 \mathrm{mg} / \mathrm{kg}$, the concentrations are considered representative of ambient conditions for the TTR. Therefore, arsenic is not 
considered to be a basis for this UR. Radiological results for soil samples are not considered to be statistically different from their respective established background levels and, therefore, are below PALs.

Although all results were less than their respective PALs, it was requested that a UR be put in place because the silver concentration exceeded residential PRGs (based on a silver concentration of 2,900 ppm at 27 to $28 \mathrm{ft}$ bgs exceeding the residential PRG of $390 \mathrm{mg} / \mathrm{kg}$ ) (DOE/NV, 2000b).

\subsection{Basis for Use Restriction Modification}

As current action levels are based on industrial PALs, described in Section 2.2, all silver results from this CAS are below the revised PAL of 9,400 mg/kg (DOE/NV, 2000b). Therefore, no contaminants are present at this site in concentrations exceeding PALs, and the revised FALs were established at the PAL concentrations.

\subsection{Proposed Modification}

Remove the FFACO UR and associated fencing and postings from this site. 


\section{References}

DOE/NV, see U.S. Department of Energy, Nevada Operations Office.

FFACO, see Federal Facility Agreement and Consent Order.

Federal Facility Agreement and Consent Order. 1996 (as amended). Agreed to by the State of Nevada; U.S. Department of Energy, Environmental Management; U.S. Department of Defense; and U.S. Department of Energy, Legacy Management.

NNSA/NSO, see U.S. Department of Energy, National Nuclear Security Administration Nevada Site Office.

U.S. Department of Energy, National Nuclear Security Administration Nevada Site Office. 2004f. NV/YMP Radiological Control Manual, DOE/NV--11718-079, Rev. 5. Prepared by Bechtel Nevada. Las Vegas, NV.

U.S. Department of Energy, National Nuclear Security Administration Nevada Site Office. 2006c. Industrial Sites Project Establishment of Final Action Levels, Rev. 0, DOE/NV--1107. Las Vegas, NV.

U.S. Department of Energy, Nevada Operations Office. 1999d. Corrective Action Investigation Plan for Corrective Action Unit 406: Area 3 Building 03-74 \& Building 03-58 Underground Discharge Points and Corrective Action Unit 429: Area 3 Building 03-55 \& Area 9 Building 09-52 Underground Discharge Points, Tonopah Test Range, Nevada, Rev. 0, DOE/NV--547. May. Las Vegas, NV.

U.S. Department of Energy, Nevada Operations Office. 2000b. Corrective Action Decision Document/Closure Report for Corrective Action Unit 406: Area 3 Building 03-74 \& Building 03-58 Underground Discharge Points and Corrective Action Unit 429: Area 3 Building 03-55 \& Area 9 Building 09-52 Underground Discharge Points, Tonopah Test Range, Nevada, Rev 0, DOE/NV--591. March. Las Vegas, NV. 


\section{Library Distribution List}

\section{$\underline{\text { Copies }}$}

U.S. Department of Energy

National Nuclear Security Administration

Nevada Site Office

Technical Library

P.O. Box 98518, M/S 505

Las Vegas, NV 89193-8518

U.S. Department of Energy

Office of Scientific and Technical Information

P.O. Box 62

Oak Ridge, TN 37831-0062

Southern Nevada Public Reading Facility

c/o Nuclear Testing Archive

P.O. Box 98521, M/S 400

Las Vegas, NV 89193-8521

Manager, Northern Nevada FFACO

Public Reading Facility

c/o Nevada State Library \& Archives

100 N Stewart Street

Carson City, NV 89701-4285
1 (Uncontrolled, electronic copy)

1 (Uncontrolled, electronic copy)

2 (Uncontrolled, electronic copies)

1 (Uncontrolled, electronic copy) 